\title{
Medical Students' Perceptions and Satisfaction with Under-Graduate Medical Hybrid Problem-Based Learning Curriculum in a Saudi Medical School
}

Lutfun Nahar ${ }^{1, *}$, Raneem Osama Salem ${ }^{1}$, Ayesha Nuzhat $^{1}$, Lamia Alakrash $^{1} \&$ Sabiq Anjum $^{2}$
Diprim

${ }^{1}$ Basic Medical Sciences Department, Faculty of Medicine, King Fahad Medical City, King Saud bin Abdulaziz University for Health Sciences, Riyadh, Saudi Arabia

${ }^{2}$ College of Medicine, Alfaisal University, Riyadh, Saudi Arabia

*Corresponding author: Anatomy Division, Department of Basic Medical Sciences, Faculty of Medicine at King Fahad Medical City, King Saud bin Abdulaziz University for Health Sciences, P.O. Box 59046, Riyadh 11525, Kingdom of Saudi Arabia (KSA). Tel: 966-288-9999 Ext: 17396, Fax: 16760 E-mail: drnahar9@gmail.com; lnahar@kfmc.med.sa

Received: July 4, 2014

doi:10.5296/ije.v6i3.5914
Accepted: August 5, 2014 Published: August 25, 2014

URL: http://dx.doi.org/10.5296/ije.v6i3.5914

\begin{abstract}
Problem-based learning (PBL) is an innovative educational approach. Any innovative curriculum needs to be evaluated for proper implementation. While it is laborious and time consuming to study the whole course curriculum, focusing on the academic activities and assessment system would provide a useful means for having an overview of the whole course. The objective of this study is to evaluate the perception and satisfaction level among medical students regarding the academic sessions and assessment method and what measures they will suggest to rectify the problem-based learning curriculum. It is a descriptive type of study. A pretested questionnaire which comprised of close-ended questions in line with the study objective was distributed to all fifth and sixth year medical students during the academic year 2012-2013. The students were highly satisfied $(\mathrm{P}<0.005)$ with PBL curriculum. Majority of students agreed that multiple-choice question is the best form of assessment but it pushed them towards the surface approach to learning. It was also evident that most of the students experienced stress by the frequent exam system. This study concluded students' satisfaction regarding the hybrid PBL curriculum and an insight into some areas which need attention in the curriculum.
\end{abstract}

Keywords: Curriculum, Perception, Problem-based learning, Satisfaction, Under-graduate 


\section{Introduction}

Curricula are commonly described or categorized in terms of the educational strategies adopted, such as problem-based learning or community orientation, or in terms of the instructional methods adopted, such as small-group work and computer-assisted learning (Harden, 1997). Problem-based learning (PBL) is a method of teaching many different kinds of skills including problem finding, rules of argumentation (Belland et al., 2011), collaboration (Berkel \& Dolmans, 2006) and peer tutoring (Shamir et al., 2008). It is an innovative educational approach. It has been considered a student-centered approach in which students determine what they need to learn (Barrows, 2002; Hmelo-Silver and Barrows, 2006). It is well known that any innovative curriculum needs to be evaluated for proper implementation (Bhargava et al., 1987; Goldie, 2006). While it is laborious and time consuming to study the whole course curriculum, focusing on the academic activities and assessment system would provide a useful means for having an overview of the whole course.

The six year medical program in the college of Medicine of King Fahad Medical City at King Saud Bin Abdulaziz University has three phases: phase one is premedical for one year, phase two is preclinical for two and half years, and phase three is clinical for two and half years. Phase one is integrated curriculum, phase two is hybrid problem based learning (PBL) curriculum and phase three is traditional curriculum. Phase two (preclinical) is divided into semesters and different blocks. In each block, students' assessment is divided into two main parts - the continuous assessment (Formative) and the end of block assessment (Summative). Formative assessment includes multiple modes of assessment such as two quizzes and one mid-block exam based on multiple-choice questions (MCQ), assessment of student participation in PBL sessions and reflective report, laboratory assignment, seminar, and summative assessment based on MCQ followed by objective-structured practical/clinical examination (OSPE/OSCE). In PBL, a problem is set for each week. Each problem is planned to help the students incorporate the various components of the week's program. Two small-group sessions, one brainstorming and one review session are scheduled in the week. This, alongside the other learning activities such as, lecture, practical, seminar, clinical skill, and self-directed learning, provide an additional focus for the student's learning.

An ongoing evaluation system is essential to determine if the academic system in place has worked to produce a better product (Manzar \& Manzar, 2011). Students are the direct beneficiary or benefactor of the system and today in many parts of the world graduates are required to complete an assessment of their curricular program for evaluation and feedback (Hesketh et al., 2003; Hyppola et al., 2000).

Proper analysis of the present situation and understanding of the students' views on PBL are essential pre-requisites for evaluation of the curricula. So, students' satisfaction and feedbacks regarding the academic sessions and assessment methods have great values to rectify the curriculum. 


\section{Methods}

\subsection{Setting and sample}

This descriptive type of study was conducted at the Faculty of Medicine, King Fahad Medical City, King Saud Bin Abdulaziz University for Health Sciences, Riyadh, Saudi Arabia. The study included (195) medical students both male (125) and female (70) of fifth and sixth year during the academic year 2012-2013.

\subsection{Ethical approval}

An ethical approval was obtained from Institutional Review Board (IRB) at king Fahad Medical City (IRB number: 13-036).

\subsection{Data collection}

First the study objectives were explained to the participants. Informed consent was taken and full confidentiality was assured to the participants. They filled out a pre-tested questionnaire which comprised of close-ended questions in line with the study objective. The questionnaires were prepared by literature review and the authors own experiences.

\subsection{Data Analysis}

The students' perception and satisfaction rate were measured by a 5 point Likert scale. The Likert scale stood for an ascending order of score (1, 2, 3, 4, and 5 standing for Disagree, Tend to disagree, Undecided, Tend to agree, and Agree respectively). Upon receipt of the participants' responses, the data were entered and processed using Statistical Package for Social Sciences (SPSS version 21) to calculate the descriptive statistics mostly percentage frequencies of responses on Likert scales. Mean scores and standard deviations were calculated wherever necessary. Any mean value above 3 was considered as inclining towards the desired results. We calculated the Pearson chi-squared test and report $\mathrm{P}$ value for statistical significance by combining all 'Satisfied' (Highly satisfied, and Satisfied) and 'Dissatisfied' (Highly dissatisfied and Dissatisfied) responses into two categories of "yes" and "no" to determine association between PBL curriculum and students satisfaction. The degree of statistical significance was set by the p-value of 0.05 . Kendall's tau test (2-tailed) was conducted to determine whether there is any significant correlation between two variables. Cronbach's $\alpha$ (alpha) test to calculate the items reliability was applied.

\section{Results}

A questionnaire containing 16 items regarding the students' views and satisfaction was given to 195 students. The overall response rate was $80.51 \%$. This represented 157 students. The results of Cronbach's alpha coefficient ( $\alpha=0.94)$ indicated that the items have a high reliability.

\subsection{Students' satisfaction with PBL curriculum}

Students' satisfaction is as shown in Table 1. The great majority of students are satisfied with 


\section{Macrothink}

PBL curricula. 80\% (126) students believe that PBL enhanced their critical thinking, interest to learning and leadership skill. In addition, most of the students agreed that learning sessions were intellectually stimulating, and PBL enabled them to work in a team and also made them look at their profession differently. It also shows that the association between students' satisfaction and PBL curricula is statistically highly significant $(\mathrm{P}<0.005)$.

Table 1. Students' satisfaction values with PBL curriculum $(\mathrm{P}$ value $=0.05)$

\begin{tabular}{llll}
\hline Satisfaction Area & $\begin{array}{l}\text { Yes } \\
(\%)\end{array}$ & $\begin{array}{l}\text { No } \\
(\%)\end{array}$ & P Value \\
\hline Make professionally different & 75.8 & 24.2 & .000 \\
Intellectually stimulating learning & 78.2 & 21.8 & .000 \\
Level of team working & 69.4 & 30.6 & .000 \\
Increase interest to learning & 79.6 & 20.4 & .000 \\
Increase critical thinking & 81.4 & 18.6 & .002 \\
Increase leadership skill & 80.1 & 19.9 & .002 \\
\hline
\end{tabular}

\subsection{Students' perception regarding the academic activities and assessment system}

Table 2 shows percent frequency, mean and standard deviation (SD) of each item of students' perception regarding the academic activities and assessment system. 79\% (124) students agreed, $15.9 \%$ (25) disagreed and 5.1\% (8) undecided that multiple modes of assessment were helpful to assess their higher level of knowledge and skills and 56.74\% (89) agreed, 31.8\% (50) disagreed and $11.46 \%$ (18) undecided that it focused on clinical knowledge rather than basic sciences. The mean of all items were above 3 which indicate positive attitude towards PBL curricula. The lowest mean (3.24) was obtained for quality of lectures and the highest mean (3.95) was obtained for seminar. The SD for all items ranked from 1.22 to 1.43.

Table 2. Students' view regarding the academic activities and assessment system

\begin{tabular}{|c|c|c|c|c|c|c|c|}
\hline \multirow[t]{2}{*}{ Statement } & \multirow[t]{2}{*}{$\mathrm{n}$} & \multicolumn{5}{|c|}{$\begin{array}{l}\text { Frequency of responses for each } \\
\text { statement }(\%)\end{array}$} & \multirow[t]{2}{*}{$\begin{array}{l}\text { *Mean } \\
\text { score } \pm \mathrm{SD}\end{array}$} \\
\hline & & Disagree & $\begin{array}{l}\text { Tend to } \\
\text { disagree }\end{array}$ & Undecided & $\begin{array}{l}\text { Tend } \\
\text { to } \\
\text { agree }\end{array}$ & Agree & \\
\hline $\begin{array}{l}\text { PBL gave you direct } \\
\text { responsibility for your own } \\
\text { learning }\end{array}$ & 156 & 10.3 & 14.7 & 12.8 & 27.6 & 34.6 & $3.62 \pm 1.36$ \\
\hline $\begin{array}{l}\text { It made you competent, so } \\
\text { that you are able to engage } \\
\text { yourself in the clinical } \\
\text { conversation in the clinical } \\
\text { phase }\end{array}$ & 156 & 7.7 & 16.7 & 13.5 & 28.8 & 33.3 & $3.63 \pm 1.30$ \\
\hline $\begin{array}{l}\text { It focused on clinical } \\
\text { knowledge rather than basic } \\
\text { sciences }\end{array}$ & 157 & 12.7 & 19.1 & 11.46 & 28.04 & 28.7 & $3.38 \pm 1.43$ \\
\hline
\end{tabular}


The block system was

155

\section{4}

11.6

2014, Vol. 6, No. 3

beneficial

Seminar increased your

$156 \quad 7.6$

8.9

6.4

34.4

$42.7 \quad 3.95 \pm 1.26$

presentation skill

The quality of lectures was

157

10.2

22.3

18.5

31.2

17.8

$3.24 \pm 1.26$

satisfactory

Multiple modes of

assessment were helpful to

$157 \quad 7.0$

8.9

5.1

50.3

$28.7 \quad 3.80 \pm 1.22$

assess your higher level of

knowledge and skills

$\mathbf{n}$ : Number of respondents for the particular statement (a total of 157 respondents responded to the questionnaire).

Each percentage value has been calculated after excluding the absence of responses.

* Each mean score represents the mean of the scores (1, 2, 3, 4 \& 5) available for the responses on an individual statement.

\subsection{Students’ view regarding MCQ}

There was a strong, positive correlation between two variables - namely MCQ is the best form of assessment and it pushed the students towards the surface approach to learning $(r=1.000, p$ $=0.000)$.

\subsection{Students' perception regarding the frequent exam system}

Students experienced stress by the frequent exam system was reflected in figure 1.

$66 \%$ (104) students agreed, 19\% (30) disagreed and 15\% (23) undecided about this issue.

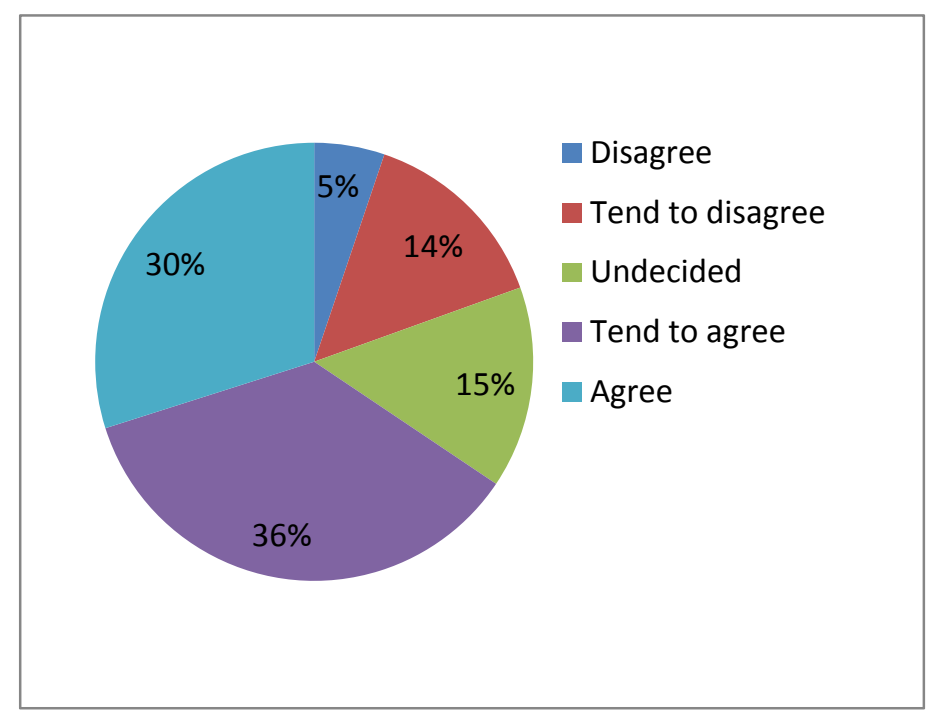

Figure 1. Pie chart showing percentage frequency of responses of students' perception that they experienced stress by the frequent exam system 


\section{Discussion}

Students' satisfaction is challenging now a days. Research showed students in PBL classrooms find learning more motivating, engaging, and satisfying (Faessler et al., 2006; Hmelo-Silver, 2004; Maxwell et al., 2001). Cockrell et al., (2000) also showed that students in PBL courses often report greater satisfaction with their experiences than non-PBL students. Manzar and Manzar (2011) reported that 57.2\% students were dissatisfied with non-PBL (Traditional) curricula. However, in our study, it is evident that in PBL curriculum 77.4\% (121) students are satisfied. This study also demonstrates PBL students perceive that they developed direct responsibility for their own learning, professionalism, critical thinking, effective communication skill, and leadership skill.

PBL is characterized as an approach to learning in which students are given more control over their learning than a traditional approach, asked to work in small groups, and most importantly acquire new knowledge only as a necessary step in solving authentic, and cross-disciplinary problems representative of professional practice (Barrows, 1996). One of its claims is to support the students in assuming the responsibility of their own learning process through their involvement in independent and self-directed study (Azer, 2009; Barrows \& Tamblyn, 1980; Campos et al., 2004; Neufeld \& Barrows, 1974). In this study, we have found that $62.2 \%$ (97) students agreed that PBL give them direct responsibility for their own learning and make them professionally different $(\mathrm{P}<0.005)$. Several studies showed that students in a PBL curriculum borrowed more books from the library than students in conventional curriculum schools (Blumberg \& Michael, 1992, Marshall et al., 1993, Rankin, 1992) which suggest that PBL students are more independent learners and take more personal responsibility for their learning (Schmidt, 2011).

The data obtained in this study indicate that PBL makes the student competent, so that they are able to engage themselves in a better way in the clinical phase (mean 3.63). It also shows that $77.1 \%$ (121) students agreed that seminar increase their presentation skill and $81.4 \%$ (128) believe that they developed critical thinking $(\mathrm{P}<0.005)$ through PBL. Liex (1996) pointed out similar concept that PBL students developed stronger thinking and problem-solving skills, effective communication skills, and sense of personal responsibility. McCaughan (2013) also mentioned during PBL session, individuals have freedom to learn, respect for individual differences and creative ideas, learning involves critical thinking, and there is excitement about the process of learning. Schmidt et al. (2011) pointed out that small tutorial group of PBL provides a platform for the development of friendships among students. In this study $69.4 \%$ (109) students are satisfied with the level of team working and they also agreed that the learning sessions were intellectually stimulating $(\mathrm{P}<0.005)$. Several studies (Hmelo-Silver, 2013; Prince et al., 2003; Savery, 2006) focus on the integration of basic and clinical sciences that occur with PBL but a few studies show slight decreases in knowledge of basic sciences (Albanese \& Mitchell, 1993; Prince et al., 2000; Vernon \& Blake, 1993). Likewise, in our study, $56.74 \%$ students agreed, $31.8 \%$ disagreed and $11.46 \%$ undecided that it focused on clinical knowledge rather than basic sciences. However, further studies are needed to test this fact. 
Cockrell et al. (2000) found that the collaborative groups fostered students' sense of ownership of the knowledge that was created over the semester in PBL curriculum. We obtained a similar result in our study. The lowest mean (3.24) was obtained for quality of lectures. By this fact, we recognize that this should be analyzed in depth.

From the results of our study, it is evident that most of the students (66\%) experienced stress by the frequent exam system. A few studies support our results and showed students' stress might have been related to the fact that they faced more frequent summative assessments (Al-Kadri et al., 2011).

Formative assessment includes multiple modes of assessment, so it enhanced students' deep approach to learning. Al-Kadri et al. (2012) also mentioned that formative assessment is likely to contribute to students' deep approach to learning while summative is likely to contribute to their surface approach. In our study, students reported positive attitudes towards MCQ but hold strong views that it pushed them towards a surface approach to learning. Similar results have been documented in studies carried out by Entwistle \& Entwistle (1991) where they found that students are very strongly influenced by the form of assessment they expect. They also mentioned that students encourage to a deep approach by using open, essay-type questions. Another study showed clearly how a change from multiple-choice to essay-type examinations had shifted the overall tendency of the students from a surface approach towards a deep approach (Thomas \& Bain, 1984). Trigwell \& Prosser (1991) suggests that deep approaches to learning are especially encouraged by assessment methods and teaching practices which aim at deep learning and conceptual understanding, rather than by trying to discourage surface approaches to learning. Another research showed that assessments tend to require explanation and comprehension and not merely memory recall and this practice may require students to use more deep learning (Emilia et al., 2012). As a consequence, teaching methods and assessment system play an important role in creating the deep learning. Nevertheless, careful planning and implementation of PBL curriculum might produce capable medical doctors who would serve the nation competently.

The limitations of this study are that we did not include all the components of PBL curriculum. In addition, it was conducted with a single medical school.

\section{Conclusion and Recommendation}

The findings of this study provide the students satisfaction with the hybrid PBL curriculum. The great majority of students believe that PBL enhanced their critical thinking, team working, interest to learning and leadership skill. This study also demonstrates PBL students perceive that they developed direct responsibility for their own learning, professionalism, and effective communication skill. Results provide an insight into some areas which need attention in the curriculum, specifically, assessment system to reduce the number of exam for diminution students' stress and include open, essay-type questions along with multiple-choice questions to enhance deep learning. We recommend doing more research to determine the level of students' satisfaction and to measure the quality of teaching-learning process and assessment system and 
its impact on students' deep learning.

\section{Acknowledgements}

The authors would like to thank Prof. Omar Hasan Kasule Sr. for his critical feedback on the statistical methods used in the study. We thank the medical students for their participation in this study.

\section{Declaration of Interest}

The authors report no conflicts of interest. The authors alone are responsible for the content and writing of the article.

This work was supported by a research grant from the Faculty of Medicine, at King Fahad Medical City, King Saud Bin AbdulAziz University for Health Sciences (Grant No. 6/34/3).

\section{References}

Albanese, M. A., \& Mitchell, S. (1993). Problem-based learning: A review of literature on its outcomes and implementation issues. Acad med: $J$ of the Assoc of Ameri Med College, 68(1), 52-81.

Al-Kadri, H. M., Al-Moamary, M. S., Magzoub, M. E., Roberts, C., \& Van der Vleuten C. P. M. (2011). Students' perceptions of the impact of assessment on approaches to learning: a comparison between two medical schools with similar curricula. International $J$ of Med Educ, 2, 44-52.

Al-Kadri, H. M., Al-Moamary, M. S., Roberts, C., \& Van der Vleuten C. P. M. (2012). Exploring assessment factors contributing to students' study strategies: Literature review. Med Teach, 34, S42-50. http://dx.doi.org/10.3109/0142159X.2012.656756

Azer, S. A. (2009). Interactions between students and tutor in problem-based learning: the significance of deep learning. Kaohsiung $J$ Med Sci, 25(5), 240-249. http://dx.doi.org/10.1016/S1607-551X(09)70068-3

Barrows, H. S., \& Tamblyn, R. (1980). Problem-based learning: An approach to medical education. New York: Springer.

Barrows, H. S. (2002). Is it truly possible to have such a thing as dPBL? Dist Educ, 23(1), 119-122. http://dx.doi.org/10.1080/01587910220124026

Barrows, H. S. (1996). Problem-based learning in medicine and beyond: A brief overview. New direct for teach and learn, 68, 3-12.

Belland, B. R., Glazewski, K. D., \& Richardson, J. C. (2011). Problem-based learning and argumentation: Testing a scaffolding framework to support middle school students' creation of evidence-based arguments. Instructional Sci, 39(5), 667-694. 
http://dx.doi.org/10.1007/s11251-010-9148-z.

Berkel, H. J. M. V., \& Dolmans, D. H. J. M. (2006). The influence of tutoring competencies on problems, group functioning and student achievement in problem-based learning. Med Educ, 40, 730-736. http://dx.doi.org/10.1111/j.1365-2929.2006.02530.x

Bhargava, I., Anand, C., \& Bhardwnj, S. (1987). Integrated curriculum on human development. New Delhi: Ministry of Health and Family Welfare, Government of India.

Blumberg, P., \& Michael, J. A. (1992). Development of self-directed learning behaviours in a partially teacher-directed problem-based learning curriculum. Teach Learn Med, 4, 3-8. http://dx.doi.org/10.1080/10401339209539526

Campos, Y. M., Morales, L. M., \& Hernandez, J. A. N. (2004). Students' assessment of problems in a Problem-based learning Pharmacology course. Adv in Health Sci Educ, 9, 299-307. http://dx.doi.org/10.1007/s10459-004-0883-2

Cockrell, K. S., Caplow, J. A. H., \& Donaldson, J. F. (2000). A context for learning: Collaborative groups in the Problem-based learning environment. Review of High Educ, 23(3), 347-363. http://dx.doi.org/10.1353/rhe.2000.0008

Emilia, O., Bloomfield, L., \& Rotem, A. (2012). Measuring students approaches to learning in different clinical rotations. BMC Med Educ, 12, 114. http://dx.doi.org/10.1186/1472-6920-12-114

Entwistle, N. J., \& Entwistle, A. (1991). Contrasting forms of understanding for degree examinations: the student experience and its implications. High Educ, 22, 205-227. http://dx.doi.org/10.1007/BF00132288

Faessler, L., Hinterberger, H., Dahinden, M., \& Wyss, M. (2006). Evaluating student motivation in constructivistic, problem-based introductory computer science courses. In $\mathrm{T}$ Reeves \& S Yamashita (Eds), Proceedings of world conference on e-learning in corporate, Government Healthcare and Higher Educ.

Goldie, J. (2006). AMEE Education guide no. 29: Evaluating educational programmes. Med Teach, 28(3), 210-224. http://dx.doi.org/10.1080/01421590500271282

Harden, R. M., Davis, M. H., \& Crosby, F. R. (1997). The new Dundee medical curriculum: a whole that is greater than the sum of the parts. Med Educ, 31, 264-271. http://dx.doi.org/10.1111/j.1365-2923.1997.tb02923.x

Hesketh, E. A., Allan, M. S., Harden, R. M., \& Mcpherson, S. G. (2003). New doctors' perceptions of their educational development during their first year of postgraduate training. Med teach, 25, 67-76. http://dx.doi.org/10.1080/0142159021000061459

Hmelo-Silver, C. E., \& Barrows, H. S. (2006). Goals and strategies of a problem-based learning facilitator. The interdisciplinary $J$ of PBL, 1(1), 21-39.

Hmelo-Silver, C. E. (2013). Creating a learning space in problem-based learning. Interdisciplinary J of PBL, 7(1), 24-39. 
Hmelo-Silver, C. E. (2004). Problem-based learning: What and how do students learn? Educ Psycho Review, $16(3)$,

235-266. http://dx.doi.org/10.1023/B:EDPR.0000034022.16470.f3

Hyppola, H., Kumpusalo, E., Virjo, I., Mattila, K., Neittaanmaki, L., \& Halila, H., et al. (2000). Evaluation of undergraduate medical education in Finnish community-oriented and traditional medical faculties: a 10-year follow-up. Med Educ, 34, 1016-1018. http://dx.doi.org/10.1046/j.1365-2923.2000.00686.x

Lieux, E. M. (1996). A comparative study of learning in lecture versus problem-based format. About teach, 50, 25-27.

Manzar, B., \& Manzar, N. (2011). To determine the level of satisfaction among medical students of a public sector medical university regarding their academic activities. BMC Research Notes, Retrieved from http:// www.biomedcentral.com/1756-0500/4/380

Marshall, J. G., Fitzgerald, D., Busby, L., \& Heaton, G. (1993). A study of library use in problem-based and traditional medical curricula. Bull Med Libr Assoc, 81(3), 299-305.

Maxwell, N. L. Bellisimo, Y., \& Mergendoller, J. (2001). Problem-based learning: Modifying the medical school model for teaching high school economics. The Social Studies, 92(2), 73-78. http://dx.doi.org/10.1080/00377990109603981

McCaughan, K. D. R. (2013). Barrows' integration of cognitive and clinical psychology in PBL tutor guidelines. Intedisciplinary $J$ of $P B L, \quad 7(1)$, 11-23. http://dx.doi.org/10.7771/1541-5015.1318

Neufeld, V. R., \& Barrows, H. S. (1974). The McMaster Philosophy: An approach to medical education. Med Educ, http://dx.doi.org/10.1097/00001888-197411000-00004

Prince, K. J. A. H. et al. (2003). Does problem-based learning lead to deficiencies in basic science knowledge? An empirical case on anatomy. Med Educ, 37, 15-21. http://dx.doi.org/10.1046/j.1365-2923.2003.01402.x

Prince, K. J. A. H., \& Van de Wiel, M. W. J. (2000). Scherpbier AJJA, van der Vleuten CPM, Boshuizen HPA. A qualitative analysis of the transition from theory to practice in undergraduate training in a PBL medical school. Adv Health Sci Educ, 5, 105-16. http://dx.doi.org/10.1023/A:1009873003677

Rankin, J. A. (1992). Problem-based medical education - effect on library use. Bull Med Libr Assoc, 80(1), 36-43.

Savery, J. R. (2006). Overview of problem-based learning: Definitions and distinctions. Interdisciplinary $J$ of $P B L, 1(1), 9-20$.

Schmidt, H. G., Rotgans, J. I., \& Yew EHJ. (2011). The process of problem-based learning: what works and why. Med Educ, 45, 792-806. http://dx.doi.org/10.1111/j.1365-2923.2011.04035.x 
Shamir, A., Zion, M., \& Spector-Levi, O. (2008). Peer tutoring, metacognitive process and multimedia problem-based learning: The effect of meditation training on critical thinking. J of Sci Educ and Tec, 17(4), 384-398. http://dx.doi.org/10.1007/s10956-008-9108-4.

Thomas, P. R., \& Bain, J. D. (1984). Contextual dependence of learning approaches: the effects of assessment. Hum Learn, 3, 227-240.

Trigwell, K., \& Prosser, M. (1991). Improving the quality of student learning: the influence of learning context and student approaches to learning on learning outcomes. High Educ, 22, 251-266. http://dx.doi.org/10.1007/BF00132290

Vernon, D. T., \& Blake, R. L. (1993). Does problem-based learning work? A meta-analysis of evaluative research. Acad Med, 68, 550-563. http://dx.doi.org/10.1097/00001888-199307000-00015

\section{Copyright Disclaimer}

Copyright reserved by the author(s).

This article is an open-access article distributed under the terms and conditions of the Creative Commons Attribution license (http://creativecommons.org/licenses/by/3.0/). 